\title{
Osmanlı Devleti’nin Son Döneminde Galatasaray Tevkifhanesi
}

\author{
Ahmet Bulut Tamgörgü*
}

(ORCID ID: 0000-0002-8943-6227)

Makale Gönderim Tarihi

21.12.2019
Makale Kabul Tarihi

24.02.2020

\section{Özet}

Sanayi Devrimi ile emek gücüne olan ihtiyacın artması modern devleti harekete geçirmiş ve nüfusu kontrol etmek için kuşatıcı bir kontrol mekanizması olmaya yönlendirmiştir. Sokaklardan ülkenin en ücra köşelerine kadar topluma saçılmayı amaçlayan bu aygıt; sokakları, hapishaneleri, fabrikaları ve okulları bir laboratuvar, insanları da veri olarak kullanmıştır. Bu durum bireyin işkence gibi yöntemlerle cezalandırılması anlayışının da değişmesine sebep olmuştur. Böylece birey; zindan gibi işlevsiz kurumlarda tutulmayacak, hapishane gibi modern, programlı ve işgücü potansiyelinin değerlendirilebileceği bir şekilde cezalandırılacaktır. Tanzimat dönemi de bu bağlamda Osmanlı Devleti için önemli dönüşümlerin yaşandığı bir süreci işaret eder. Bu sürecin önemli gelişmelerinden biri de XIX. yüzyıl itibariyle devletin ceza mekanizmasını, çıkardığı kanunlarla hukuki olarak desteklemesi, ardından modern mahkemeleri ve savcılık kurumunu tesis etmesi olmuştur. Bununla birlikte devletin klasik çağlardan beri suçluları cezalandırmak için kullandığı zindanlar, işkence odaları da dönüşerek yerini modern hapishane ve tevkifhanelere bırakmışır. Bu çalışmada ise Osmanlı Devleti'ndeki hapishanelerin ve hukuki reformların, klasik çağlardan modern çağlara doğru uzanan değişim sürecine kısaca değinilecektir. Çalışmanın esas noktası ise 1919 yılında Beyoğlu Galatasaray Tevkifhanesinin durumu, firar vakaları ve Mekteb-i Sultani ile oluşan organik komşuluk bağının yarattığı sorunlar olacaktır.

Anahtar Kelimeler: Galatasaray Lisesi, Beyoğlu Hapishanesi, Firar, İstiklal Caddesi, Tevkifhane

* Yüksek Lisans Öğrencisi, Ege Üniversitesi, Sosyal Bilimler Enstitüsü, Tarih ABD, buluttamgorgu@yahoo.com.

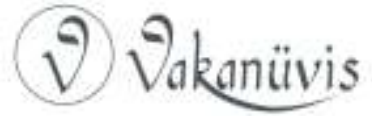




\title{
Galatasaray Prison in the Last Days of Ottoman Empire
}

\begin{abstract}
After Industrial revolution, labor power has been increased dramatically and the governments have worked on the population issue. Places peopled in the whole country was like the laboratory for them to access data related to people and their circumstances, to comprehend the nature of human behaviors. Therefore, the progress caused a paradigm shift for most particularly administrative mentality. In the meantime, factories, prisons, schools fabricated the political discourse for capital and governments with the new political- administrative tendency. In Western Europe, as one of these institutions, prisons as well as the punishment system applied there were reversed and restructured for controlling the population. In the Tanzimat Era, Ottoman bureaucracy like many other countries applied the prison reformation. Subsequently, dungeons with working on torture were overturned to modern prison in Ottoman Empire. The modern prison and punishment system of Western Europe have similarly been tried to copy to the empire. This study aims to explain how to work the prisons in the premodern period and the transformations during the Tanzimat Era in the Ottoman Empire. Thereafter, it focuses on the history of Beyoğlu Prison which is located nearby Galatasaray High School. Depending on the Ottoman Archives, in 1919, the prison break narratives in the prison and the vivid neighborhood with the school will be discussed as well.
\end{abstract}

Keywords: Galatasaray High School, Beyoğlu Prison, Prison Break, Istiklal Street, Dungeon

\section{Zindan, Tevkifhane ve Modern Hapishane}

Zindan, asırlar boyunca hem bir ceza infaz hem de cezanın infazının gerçekleştirilmesine kadar geçen sürede tutuklulara ev sahipliği yapan bir mekân olarak kullanılmıştır. Rutubetli, güneşin girmediği ve çoğu zaman sağlıksız olan bu yapılarda yüzyıllar boyunca işkenceler nedeniyle çığlıklar yükselmiş, ölümler yaşanmıştır. ${ }^{1}$ Bahsedilen kasvetli atmosferin misafirleri, sadece yönetilenler değil çoğu zaman yönetenler olmuştur. Yöneticilerin zindanlarda kısa süreli

1 Zindanlardaki kötü koşullarla ilgili olarak bknz. Samira Kortantamer, “Memlükler'de Hapishaneler", Hapishaneler Kitabı, 2010, s. 93-101.

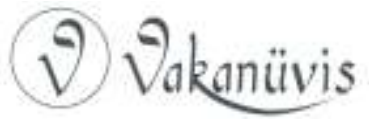


tutukluluklarının ardından salıverildikleri ve zaman zaman da idam edildikleri²; yönetilenlerin ise çeşitli yerlere sürgüne gönderildiğ ${ }^{3}$, cezirebent, kalebent olarak çalıştırıldıkları görülmektedir. ${ }^{4}$

Modern hapishanelerin tesisi ile alakalı sistematik çalışmalar 18. yüzyılın sonunda Batı Avrupa'da, Sanayi Devrimi'nin şehirlerde yaratmış olduğu etkilerle paralellik arz etmektedir. Artan nüfus, sınıflar arası gerilim gibi hususlar suç unsurlarının artmasına sebebiyet vermiştir. Bu durum, yeniden şekillenen şehirlerin güvenli ve sistemli yönetiminde modern hapishaneleri gerekli kılmıştır. Bedene yönelik işkencenin yapılageldiği sağlıksız binalar olan zindanların yerine; sistemli, temiz ve sağlıklı şartlar altında cezalandırmanın yapıldığı modern hapishaneler işleme sokulmaya başlanmıştır. ${ }^{5}$ Osmanlı Devleti'nde ise modern hapishanenin tesisine ancak Tanzimat döneminden sonra başlanabilmiştir.

Tanzimat Fermanı ise Osmanlı Devleti'nin idari, hukuki, sosyal vb. birçok yönden değişmesine sebep olmuştur. 1840 yılında düzenlenen ceza kanununda, vezir ile çobanın ve tüm uyrukların eşitliği vurgulanmıştır. ${ }^{6}$ Hâlihazırda klasik dönemde yargıçlık görevinin yanı sıra yürüttüğü idari ve mali görevlerini II. Mahmut dönemi reformlarıyla birlikte çeşitli nezaretlere bırakan kadılık kurumu, özellikle Tanzimat'tan sonra da nizamiye mahkemelerinin kurulmasıyla

2 Necdet Öztürk, “Osmanlılarda Hapis Olayları (1300- 1512)”, Hapishaneler Kitabı, İstanbul, 2010, s. 127.

3 Ali Eftal Özkul, "XVIII. Yüzyılın İlk Yarısında Kıbrıs'ta Kalebentler ve Cezirebentler", Hapishaneler Kitabı, İstanbul, 2010, s. 130- 143: Kıbrıs sürgün için kullanılan en yoğun bölgelerden biriydi çünkü hem zor ve kötü hava şartları nedeniyle mahkûmların cezalandırıması için idealdi hem de ada olması nedeniyle kaçma imkânı çok zayıftı.

${ }^{4}$ Fatmagül Demirel, "Osmanlı Adliye Teşkilatında Yaşanan Sorunların Hapishanelere Yansıması (1876- 1909)", Osmanlı'da Asayiş, Suç ve Ceza, Der: Levy, N., Toumarkine, A., İstanbul, 2007, s. 190- 200.

${ }^{5}$ Avrupa'da modern hapishanelerin kurulması ile ilgili detaylı bilgi için bknz. Gültekin Yıldız, Mapushane Osmanlı Hapishanelerinin Kuruluş Serüveni (1839- 1908), Kitabevi Yayınları, İstanbul, 2012, s. 55- 66; Mitchel P. Roth, Göze Göz Suç ve Cezanın Küresel Tarihi, Can Yayınları, İstanbul, 2017, s. 172- 233.

6 Gülnihal Bozkurt, "Tanzimat ve Hukuk", Tanzimat'ın 150. Yıldönümü Uluslararası Sempozyumu, Ankara, 1994, s. 271- 285.

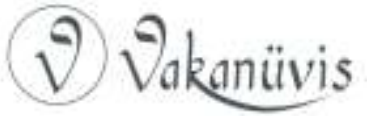


gittikçe etkisini yitiren bir karar merci haline gelmiştir. ${ }^{7}$ Buna ek olarak ilk ceza kanunu her suç için verilmesi gereken cezayı belirlemeyi hedeflemiş, böylelikle kadılık kurumunun kendi ilkeleri doğrultusunda davaları sonuçlandırma hakkı daraltılmıştır. 1851 yılında çıkarılan kanunda ise suçlar; uyrukların şeref ve haysiyetlerine, mallarına karşı işlenen suçlar olarak tasnif edilmiştir. 1858 yılındaki ceza kanunuysa, 1810 Fransız Ceza Kanununun doğrudan bir çevirisi ile hazırlanmıştır. Daha önceki kanunlardan farkı ise bireysel hakların korunması ${ }^{8}$ ve kamu düzenine aykırı işlenen suçların, şikâyet olmasa dahi devletçe cezalandırılmasıdır. ${ }^{9}$ Modern ceza mahkemeleri ve Savcılık Kurumu da ayrıca düzenlemiştir. ${ }^{10}$ Tüm bu önemli adımlar kısa sürede atılmış ve böylelikle Osmanlı Devleti'nin geleneksel hukuki kurumları değişim sürecine girmiştir.

Osmanlı Devleti'nde modern hapishanelerin kurulması ya da zindandan farklı bir işleyişin uygulanması ise yine hukuksal çerçevenin dönüşümü ya da suçlunun tanımıyla ilişkilidir. Avrupa'da Sanayi Devrimi ile emek gücüne olan ihtiyaç artmış ve bu nüfus kapital olarak değerlendirilmiştir. Modern devlet ise bu ihtiyaç doğrultusunda, nüfusu kontrol etmek istemiş bunun için çeşitli yöntemler geliştirmiştir. Kapitalizm özellikle işgücü ve üretim bağlamında devamlılı̆ını sürdürebileceği kendi formlarını üreten mekânları gerekli kılmış; hapishaneler, fabrikalar, okullar bu doğrultuda benzer işlev ve formları üretmeyi amaçlayarak iktidarı-kapitali besleyen önemli politik mekânlar haline gelmiştir. ${ }^{11}$ iktidarın kılcal bir şekilde tüm alanlara,

7 ilber Ortaylı, Hukuk ve Idare Adamı Olarak Osmanlı Devleti'nde Kadı, İstanbul, 2018, s. 91.

8 Kent F. Schull, Prisons in the Late Ottoman Empire Microcosms of Modernity, Edinburgh, 2014, s. 27.

9 Kent F. Schull, "Tutuklu Sayımı: Jön Türklerin Sistematik Bir Şekilde Hapishane İstatistikleri Toplama Çalışmaları ve Bunların 1911-1918 Hapishane Reformu Üzerine Etkileri", Osmanlı'da Asayiş, Suç ve Ceza, Der: Levy, N., Toumarkine, A., İstanbul, 2007, s. 218- 219.

${ }^{10}$ Gülnihal Bozkurt, a.g.m. s. 273- 274.

${ }^{11}$ Hasan Şen, "Osmanlı'da Hapishane Mefhumu" Osmanlı'da Asayiş, Suç ve Ceza, Der: Levy, N., Toumarkine, A., İstanbul, 2007, s. 207; Michel Foucault, Hapishanenin Doğuşu, İmge Kitabevi, Ankara, 1992, s. 245- 257; Konu ile ilgili ayrıca bknz. Michel Foucault, iktidarın Gözü Seçme Yazılar 4, Ayrıntı Yayınları, İstanbul, 2012, s. 84- 106.

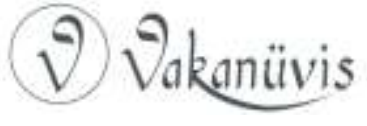


mekânlara yayılma ve toplumu kontrol etme arzusunu doyurabilecek Comteçu-pozitivist sosyal bilim anlayışı ise hapishaneleri laboratuvar, insanları ise veri olarak görmüş ve bu çalışma sistemiyle de ölçülebilir bilimsel sonuçlara vardıklarını savunmuşlardır. ${ }^{12}$

Bu doğrultuda bir çalışma sistemi ve zindandan hapishaneye geçiş konusunda durum tespiti, İngiliz büyükelçi Canning'in bizzat çalışmasıyla başlamıştır. Osmanlı İmparatorluğu topraklarında faaliyet gösteren konsoloslara 30'ar soruluk anketlerin cevaplarıla birlikte İstanbul'a gönderilmesini isteyen Canning, gelen anketlerden sonra detaylı bir rapor hazırlamıştır. ${ }^{13}$ Hazırladığı raporlara göre; istenilen düzeyde ve kalitede bir hapishanenin bulunmadığından bahsetmesinin yanı sıra, tam donanımlı bir hapishanenin hangi özelliklere sahip olması gerektiğini maddeleştirerek açıklamış ve İstanbul'da açılacak olan hapishanenin tüm ülkede emsal bir nitelikte olması gerektiğinin altını çizmiştir. ${ }^{14}$ Bu çalışmalar sonucunda eski Osmanlı ceza sisteminde suçun tespitine veya itirafına kadar tutukluluk ve işkencenin mekânı olan zindan, yerini yeni hapishanenin çalışma tarzına, suçlunun daha programlı ve sistemli bir şekilde tutulup cezasının dönüştürülmesiyle sonuçlanacak sürece devretmiştir. ${ }^{15}$

Modern hapishaneye geçiş ya da bir başka deyişle ilk Osmanlı Umumi Hapishanesi inşa çalışması, 1870 tarihinde, daha sonra Sultanahmet'te bulunan Mehterhane olarak anılmaya devam edecek bölgede başlamıştır. ${ }^{16} 1879$ yılında Sultanın emriyle hapishanelerin mevcut durumunun tespiti için bir müfettiş görevlendirilmiş ve teftişin sonunda düzenlenen raporda ise hapishanenin iç idaresindeki sıkıntılar, eksiklikler için alternatifler üretilmesi gerektiği belirtilmiş ve 1880 yılında bir nizamname çıkartılmıştır. ${ }^{17}$ Altı bölüm doksan yedi maddeden oluşan bu nizamname, hapishanelerle ilgili olarak önemli

12 Yıldız, a.g.e., s. 427; Ayrıca bknz. Gulbenkian Komisyonu, Sosyal Bilimleri Açın, Metis Yayınları, İstanbul, 2012.

13 Schull, a.g.e., s. 26: Türkiye'deki hapishanelerin gelişimi için memorandum olarak isimlendirilen bu rapor Sultan Abdülmecid'e sunulmuştur.

14 Yıldız, a.g.e., s. 110- 112.

15 Şen, a.g.m., s. 207- 208.

16 Yıldız, a.g.e., s. 384.

17 Yıldız, a.g.e., s. 380- 386.

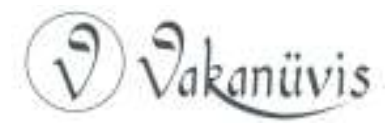


bir bürokratik reform getirmesinin yanı sıra hapishanenin işleyişine dair temel bir çerçeve sunmaktadır. Tevkifhane ve hapishane ayrımının yapıldığı, müdür ve gardiyanlık gibi çalışanların belirlendiği, yiyecekiçecek, mahkûmların çalışma durumları vb. birçok konuda bilgiler içeren nizamname, Cumhuriyet döneminde de yürürlükte kalmıştır. ${ }^{18}$ Ancak bu nizamnamenin hemen işleme sokulamadığı 1881 yılında yapılan bir teftişten anlaşılmaktadır. İstenilen alternatiflerin üretilememesinin en önemli nedenlerinden biri ise Duyun- Imumiye Idaresi'nin Osmanlı ekonomisine vurduğu darbedir. ${ }^{19}$

Ittihat ve Terakki Cemiyeti iktidarı ise hapishaneler konusunda dönüm noktasını işaret etmektedir. Dâhiliye Nezareti bünyesinde başarılı çalışmalar yapan yeni iktidar, ${ }^{20} 1880$ tarihli nizamnameyi pratiğe dönüştürmeye çalışmıştır. Bu konuyla ilgili olarak Dâhiliye Nezaretinde Hapishaneler Idare-i Umumiye Müdüriyeti oluşturarak tüm imparatorluktaki hapishaneleri tek bir merkeze bağlamayı hedeflemiştir. 1909- 1911 yılları arasında merkezi bir ceza politikası uygulanmaya çalışılmış, hapishane bina mimarisinin tek tip olması hususu önemsenmiştir. ${ }^{21}$ Yine de II. Abdülhamid döneminde nasıl Duyun-ı Umumiye İdaresi'nin ekonomik baskısı olduysa, İttihat ve Terakki için de Trablusgarp Savaşı ${ }^{22}$, Balkan Savaşları ve I. Dünya Savaşının yaratmış olduğu ekonomik problemler, hapishaneler konusunda istenilen başarının sağlanmasında bir gecikmeye sebep olmuştur. ${ }^{23}$ Yine de bu sürede hiçbir şey yapılmamış değildir. Almanya'dan Paul Pollitz isimli bir uzman getirilmiş, hapishanelerle ilgili olarak imparatorluğun her köşesinden önemli bilgiler merkezde toplanmaya çalışıımıştır. Schull'a göre İttihat ve Terakki Cemiyeti, 1917 gibi Dünya Savaşı'nın en yoğun yaşandığı bir tarihte hapishaneler ve mahkûmlar hakkında böylesine detaylı bilgiler toplayarak, modern,

\footnotetext{
18 Yıldız, a.g.e., s. 380- 386.

19 Yıldız, a.g.e., s. 378- 380.

20 Schull, a.g.m., s. 234.

${ }^{21}$ Demiryürek, a.g.e., s. 25- 30.

22 Kurtuluş Demirkol, II. Meşrutiyet Döneminde Edirne Vilayeti Hapishaneleri, Yayınlanmamış Doktora Tezi, Sakarya, 2012, s. 97.

${ }^{23}$ Yasemin Saner Gönen, “Osmanlı'nın Yüzlerce Yıl Süren Cezalandırma ve Korkutma Refleksi: Prangaya Vurma", Osmanlı'da Asayiş, Suç ve Ceza, Der: Levy, N., Toumarkine, A., İstanbul, 2007, s. 176; Demiryürek, a.g.e., s. 25- 30.
}

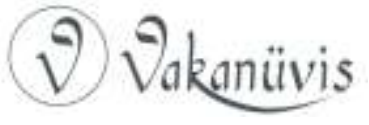


medeni bir toplum ve ulus yaratmak için bu verileri kullanmak istemiştir. ${ }^{24}$ Dâhiliye Nezaretinin çalışmaları sadece hapishaneler, bir başka deyişle içeridekiler olmamış, aynı zamanda Emniyet-i Umumiye Müdüriyeti gibi kurumlarla dışarıdaki serserilerin, başıboşların da takibi yapılmaya çalışılmıştır. ${ }^{25}$ Özetle nüfus ile ilgili önemli mesai harcayan ittihat ve Terakki Cemiyeti, İstanbul'un en karanlık sokaklarından, imparatorluğun sınır boylarına kadar erişim sağlamaya uğraşmış ve nüfusu kontrol etmeye çalışmıştır. ${ }^{26}$ Tutuklu ve mahkumlar da nüfusun bir parçası olarak bu verilerin bir bölümünü oluşturmuştur.

\section{Beyoğlu- Galatasaray Tevkifhanesi}

Osmanlı İstanbul'u ile neredeyse yaşıt, eski ve kullanıma uygun olmayan zindanlar yerine ilk modern anlamdaki hapishane inşası çalışmaları 1870'ten sonra Sultanahmet Meydanı'nda bulunan Mehterhane'de başlatılmıştır. ${ }^{27}$ Eski binaların yenilenmesinin yanı sıra hukuki düzenlemelerle de hapishane ve tevkifhanelerdeki çalışma sistemi yeni bir çerçeveye oturtulmaya çalışılmıştır. Bu açıdan 1880 tarihinde yürürlüğe giren nizamname ciddi bir önem arz etmektedir. Hapishaneler hakkında detaylı bir işleyiş biçimi sunan bu nizamnameye göre; her vilayet, liva ve kazada tevkifhane bulundurulması gerekmektedir. Ek olarak tevkifhane ve hapishane ayrımı yapılmıs; tevkifhanelerde sorgulanmakta ve yargılanmakta olan kimselerin, hapishanelerde ise mahkûmların tutulması gerektiğinin altı çizilmiştir. ${ }^{28}$ $\mathrm{Bu}$ yetkin, teferruatlı olan nizamname II. Abdülhamid döneminde yürürlüğe girmiş olsa da meyvelerinin toplanması ancak İttihat ve Terakki iktidarıyla mümkün olabilmiş, Trablusgarp, Balkan ve I. Dünya Savaşlarının yaratmış olduğu ekonomik sıkıntılar bu hususta ilerleyişi engellemiştir. ${ }^{29}$

Beyoğlu Tevkifhanesinin kuruluş tarihi tam olarak tespit edilememektedir. Yine de her vilayet merkezi ve livaya tevkifhane

\footnotetext{
${ }^{24}$ Schull, a.g.m., s. 236.

${ }^{25}$ Schull, a.g.m., s. 230.

${ }^{26}$ Schull, a.g.m., s. 230.

27 Yıldız, a.g.e., s. 268- 269.

${ }^{28}$ Saner Gönen, a.g.m., s. 174.

${ }^{29}$ Demirkol, a.g.e., ss. 216- 218.
} 
açılmasını vurgulayan bu nizamname doğrultusunda, binanın 1880 yılından sonra kullanılmaya başlandığı tahmin edilebilir. ${ }^{30}$ Beyoğlu Tevkifhanesi ya da bazı belgelerde Galatasaray Tevkifhanesi olarak geçen bu bina, Yeni Çarşı Sokağı ile Cadde-i Kebir'in kesiştiği yerde konumlanmaktadır. ${ }^{31}$ Haritadan $^{32}$ da görüleceği üzere, Beyoğlu'ndaki tüm karakollar üzerinde söz sahibi olan Beyoğlu Mutasarrıflığı bulunmaktadır. ${ }^{33}$ Mutasarrıflığın bölgedeki suçluların takibi ve yakalanması konusunda önemli bir işlevi bulunmaktadır. ${ }^{34} \mathrm{Bu}$ doğrultuda aşağıda tartışılacak olan özellikle gardiyanların ihmali neticesinde Mekteb-i Sultani'ye atlanılarak yapılan firar hadiselerini engelleme konusunda bu mutasarrıflıktaki görevlilerin rolü büyüktür.

Cadde-i Kebir üzerinde Mekteb-i Sultani'ye komşu olan bu tevkifhane, içerisinde hamam ve yemekhanenin bulunmaması gibi hususlar düşünüldüğünde amacının dışında yapılmış olmalıdır. ${ }^{35}$ Tevkifhanenin alt katında iki, üst katında üç koğuş bulunmaktadır. Bu odalar, güneşsiz, havasız ve rutubetlidir. Ayrıca kadınlar için de bir hücre mevcuttur. ${ }^{36}$ Düvel-i Mütelife Fevkalade Komisyonunun 1919 yılında hapishaneye dair sunduğu raporlarda binanın çoğu yerinin kirli olduğu, döşeme tahtalarının silinip süpürülmeye, duvarlarının badana yapılmaya ihtiyacı olduğu vurgulanmaktadır. ${ }^{37}$ Özellikle bodrum katındaki odaların yirmi dört saatten fazla kimsenin barınamayacak koşullarda olduğu ve bir günden fazla kimsenin burada hapsedilmemesi gerektiği ısrarla altı çizilen bir konu olmuştur. ${ }^{38} 1921$ yılında Amerikalıların tevkifhaneye yapmış oldukları ziyarette çeşitli

30 Mümin Yıldıztaş, Mütareke Döneminde Suç Unsurları ve istanbul Hapishaneleri, Yayımlanmamış Yüksek Lisans Tezi, İstanbul, 1997, s. 44- 45.

${ }^{31}$ Noemy Levy-Aksu, Osmanlı İstanbulu'nda Asayiş 1879- 1909, İstanbul, 2017, s. 380.

32 Ek-1, Levy-Aksu, a.g.e., s. 381.

${ }^{33}$ Ek-2, Sultan II. Abdülhamid Dönemi Fotoğrafları, Beyoğlu Mutasarrıflığının fotoğrafı.

34 Levy-Aksu, a.g.e., s. 380.

35 Yıldıztaş, a.g.e., s. 44.

${ }^{36}$ Halim Demiryürek, Osmanlı Hapishaneleri (1913- 1914), Babıali Kültür Yayıncılığı, İstanbul, 2019, ss. 33- 34.

37 Başbakanlık Osmanlı Arşivi (BOA), Dahiliye Nezareti Mebânî-i Emîriye ve Hapishâneler Müdüriyeti Belgeleri BOA. DH.MB. HPS. M, 38/ 105. 2, tarihi yok.

38 BOA, DH.MB. HPS. M, 38/ 105/ 1, 22 Temmuz 1335 (22 Temmuz 1919).

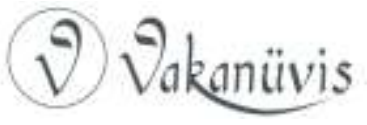


olumlu gözlemlerin olması, bahsedilen raporlardan hareketle binaya dair çeşitli iyileştirilmeler yapıldığını göstermektedir. ${ }^{39}$

\section{Tutuklu ve Mahkumların Durumları: "Inmeyeceğim Ne Yapacaksın" 40}

Mümin Yıldıztaş'ın 1997 yılında yazmış olduğu Mütareke Döneminde Suç Unsurları ve İstanbul Hapishaneleri isimli yüksek lisans tezinde vermiş olduğu bilgiler doğrultusunda 1919 yılında Beyoğlu Tevkifhanesindeki tutukluların "hal"ini anlamak adına rakamlardan bahsetmek faydalı bir başlangıç olacaktır. Yılın başında sadece 66 erkeğin bulunduğu tevkifhanede, yıl boyunca $26^{\prime}$ sı kadın toplam 648 suçlu tutulmuştur. Toplam tutuklulardan 212'si tahliye edilmiş, 241'i Hapishane-i Umumi'de mahkûm olmuş, 214'ü de Dersaadet Tevkifhanesine sevk edilmiştir. ${ }^{41}$ Bir yılda toplam 714 kişinin, ağır bir şekilde işleyen hukuk sistemi nedeniyle gereğinden fazla bekletildiği ${ }^{42}$ bu tevkifhanede ise yaşam koşullarının yukarıda da bahsedildiği üzere pek de iç açıcı olmadığı açık bir şekilde görülmektedir.

Tevkifhanenin 1919 yılında karşılaştığı en büyük sıkıntılardan bir diğeri ise sınırlı kapasitenin getirdiği izdiham sorunudur. Uzun süren davalar neticesinde gereğinden fazla süre tevkif edilen kimseler için,

\footnotetext{
${ }^{39}$ Yıldıztaş, a.g.e., s. 44- 45: 1921 yılında Amerikalıların yaptıkları ziyaret: "Mahkumlar altı odada tutuluyor, hapishanenin kuramsal kapasitesi 50 kişi olmakla birlikte ziyaretimiz esnasında burada 59 hükümlü bulunmaktaydı her biri yaklaşık 4,5 m2 büyüklügündeki iki odanın her birinde onar kişi mevcut, odalarda sadece çok küçük bir pencere var, pencere çok yüksekte ve burada ancak $69 \mathrm{~cm} 2$ lik hafif bir ışık ve $30 \mathrm{~cm} 2$ lik hava girebiliyor 15 metreye 2,40 metre büyüklügünde ve bütün odaların en genişi olan bir başka odada yine aynı büyüklükteki iki pencere mevcut, burada ise 20 kişi yaşıyor. 6,30 metreye 4, 50 metre büyüklügünde diğer bir odanın da yine iki penceresi var, ancak burada sadece 8 kişi bulunduğundan ışık ve hava oranı biraz daha iyi sayılabilir. En iyi durum da olan bölme, kadınlar için ayrılmış olan oda olup 9 metreye 3,90 metre büyüklüğündeki bu oda da binanın güneşli kısmına açılan dört pencere var."

40 Demiryürek, a.g.e., s. 33- 34: Halim Demiryürek, 1913- 14 yılları arasında Galatasaray Tevkifhanesi ile ilgili olarak verdiği bilgilerde tevkifhanede sadece tutukluların bulunması gerekirken, mahkumların bulunduğundan söz etmektedir. Ancak bu çalışmada faydalanılan arşiv vesikalarında odak yapılan yıl 1919'dur. Yer yer firar vakalarında mahkûm kavramı kullanılsa da ağırlıklı olarak tutuklu olduğu görülmektedir.

41 Yıldıztaş, a.g.e., s. 46- 47.

42 Yıldıztaş, a.g.e., s. 74- 79.
}

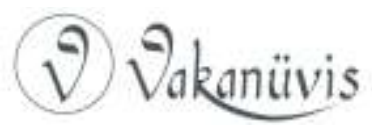


bu odalar, dört kişiden fazla sığmayacak derecede küçük bir mecrada on iki ve on beş günden beri yirmi altı kişinin kalmak zorunda olduğu tâkat-fersa yani dayanılmaz yerlerdir. Bu bağlamda 1919 yılında Tepebaşı Bahçesinde sarhoşluk suçu işleyen bir adamın üç aydan beri Beyoğlu Tevkifhanesinde tutulması ve katil suçlamasıyla uzun süredir mahkemeye çıkarılmamış bir kadının varlığı, geç kalan yargı sürecini desteklemek adına örnek olarak gösterilebilir. ${ }^{43}$ Yukarıda değinilen Amerikalıların 1921 yılındaki ziyaretleri sırasında hapishane kapasitesiyle ilgili olarak elli kişilik bir rakamdan söz ettikleri ancak 1919 yılında Dahiliye Nezaretine yazılan çeşitli yazılarda bahsettiği tutuklu rakamları yüz elliye yaklaşmış olup, üç katına ulaştığı bilgisi geçmektedir. ${ }^{44} \mathrm{Bu}$ doğrultuda bazen bu sayının iki katına çıktığını ve tutukluların sıhhat ve nizamın temini için ìstanbul Merkez Tevkifhanesine gönderilmesi gerektiğine dair ihbarlar da yapılmaktadır. ${ }^{45}$

Bir diğer önemli husus ise sağlık koşullarıdır. Dâhiliye Nezaretine Ingiliz Fevkalade Komiserliğinden gelen bir takrirde, tutukluların bitlerden ve pirelerden şikâyet ettiği, çoğunun kaşınmakta olduğu ve sürekli kirli çamaşırla yaşamak zorunda kalan tutukluların çamaşırlarını yenileriyle değiştiremediğinden bahsedilmektedir. Hamam intiyacı da bu tutukevi için büyük bir sorun teşkil etmektedir. Hapishane olarak tasarlanmamış bu binada hamamın olmaması nedeniyle, tutukluların bu ihtiyacını da ancak haftada iki kez bostan pazarına giderek halledebildiğini yine bu takrirden öğrenmekteyiz fakat günde sadece on kişinin hamama gitmesine izin verilmesi nedeniyle bir mahkûmun ancak beş haftada bir hamam ihtiyacını karşılayabilmesi söz konusudur. ${ }^{46}$ Ayrıca izdiham nedeniyle bina temizliğine de dikkat edilmeyen bu tevkifhanede kirli, dezenfekte edilmemiş abdesthaneleri, kadınlar ve erkekler ortak kullanmak zorunda kalmışlardır. ${ }^{47}$ Düvel-i Mütelife Fevkalade Komisyonlarının "Hapishanenin darlığı ve gayri sıhhîliği dolayısıyla mevkufin ve mahkumin bu şerait dâhilinde orada üç

\footnotetext{
43 BOA, DH. MB. HPS. $M, 38 / 105 / 2$, Tarihi Yok.

${ }^{44}$ BOA, DH. MB. HPS. M, 38/ 74, 9 Temmuz 1335 (9 Temmuz 1919).

45 BOA. DH. MB. HPS. M, 39/ 8, 4 Mayıs 1335 (4 Mayıs 1919).

${ }^{46}$ BOA, DH. MB. HPS. M, 38/105/2, tarih yok.

47 BOA, DH. MB. HPS. M, 38/ 74, 9 Temmuz 1335 (9 Temmuz 1919).
}

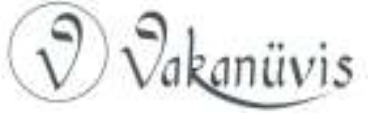


gün bile gayri insani bir muameledir."148 gibi bir yorum durumun vahametini gösterir niteliktedir.

Son olarak "inmeyeceğim ne yapacaksın" başlığının tercih edilmesinin nedeniyse, bu kötü koşullar altında yaşamak zorunda kalan bir mahkûmun (Beyoğlu Tevkifhanesinde mahkûm olduğundan emin olmamakla birlikte), kendi sesinin ve itiraz çığlığının belgelere doğrudan yansımasıdır. ${ }^{49} 27$ Temmuz 1919 yılına tarihlenen bu belgede, Lazkiyeli İbrahim namındaki bir şahsın hapishaneye ait minareye çıkarak etrafa mendil salladığını gören jandarma nöbetçi nazırın ısrarla yaptığı ihtarlara aldırış etmeyerek, ayrıca "inmeyeceğim ne yapacaksın" cevabını vermesinin ardından, nazır, anlaşılan korkutmak maksadıyla havaya bir kez ateş etmiş sonra bu hadise kapanmıştır. Birçok çıkarım yapılabilecek bu olayda ilk soru elbette Lazkiyeli İbrahim'in ne yapmak istediği olsa da ne yazık ki arşivde buna dair bir evrak tarafımızca bulunamamıştır. Bir mahkûm neden hapishane minaresinden etraftaki hanelere mendil sallar; bu belki bir meczubun hareketi, belki planlanan iyi bir kaçış planının parçası ya da tüm bahsedilen kötü koşulların sembolik bir fotoğrafıdır. Kesin bir sonuca varamasak bile yine de bu renkli öykü, aşağıda tartışılacak olan firar ve firarda gardiyanların eksikleri nedeniyle mahkûmların başına buyruk hareket edebildiklerini destekler bir örnektir. ${ }^{50}$

\section{Firar Vakalarında Müdür ve Gardiyanın Rolü}

Tanzimat devri sıkı bir şekilde merkezileşmeye ve bu doğrultuda yeni bürokratik kurumların inşasıyla modern memuriyete doğru kırılmayı temsil eder. ${ }^{51}$ Hapishane ve tevkifhanelerde yaşanılan firar hadiselerinde karşılaşılan en büyük sıkıntılardan biri de gardiyan ve müdürlerin bu krizlerde nasıl konumlandıklarıdır. Merkezi devletin veya bir başka deyişle modern devletin, toplumu panoptik bir biçimde kuşatma arzusu, nüfusun kontrol edilebilmesiyle ve ya toplumun bu aygıt tarafından sürekli görülebilir olduğu izlenimini vermesiyle doğru

\footnotetext{
48 Yıldıztaş, a.g.e., s. 44- 45.

49 BOA, DH. MB. HPS. M, 38/ 121, 27 Temmuz 1335 (27 Temmuz 1919).

50 BOA, DH. MB. HPS. M, 38/ 121, 27 Temmuz 1335 (27 Temmuz 1919).

${ }^{51}$ Ali Akyıldız, Osmanlı Bürokrasisi ve Modernleşme, İstanbul, 2012, s. 23- 29.
}

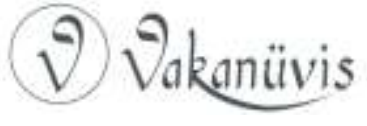


orantılıdır. $^{52} \mathrm{Bu}$ tarz bir aygıt Osmanlı Devleti'nde teorik olarak uygulanmaya çalışılmışsa da pratik açıdan yetersiz kalmıştır. ${ }^{53}$ Konu özelinde ise hapishanelerdeki sorunların başrol oyuncuları gardiyan ve müdürdür.

Bu doğrultuda meydana gelen açık ise hapishane ve tevkifhane sakinleri tarafından fırsata çevrilmiştir. İçerideki nüfusla yani tutuklularla devletin ilişkisini sağlayan gardiyanların; maddi zorluklar nedeniyle görevlerini ihmal etme, firara göz yumma vb. usulsüzlüklere meyilli olmaları merkezileşmeye, modern bir aygıt olmaya çalışan Osmanlı Devleti için önemli sorunlar teşkil etmektedir. ${ }^{54}$ Gardiyanların bu şekilde hareket etmeleri ise, devletin gözetleme ve kontrol arzusu karşısında, tutuklular için kendi rejimlerini istedikleri gibi yaşayabildikleri ve hatta bunu dayatabildikleri soyut bir mekânla bizi karşı karşıya bırakmaktadır. Ebubekir Sofuoğlu'nun bugünkü koğuş ağalığına benzer bir vakayı örneklemesi bu açıdan tutukluların kendi hürriyet alanlarını koruduklarına delil olarak gösterilebilir. ${ }^{55}$ Ek olarak Gültekin Yıldız'ın bahsetmiş olduğu i̇stanbul Hapishanesinde Esas adı Abdullah olan Arap Abdo lakaplı bir kabadayının, mahkûmiyeti sırasında gardiyanlara istediğini yaptırabilmesi örneği de kendi rejimlerini dayatmaları konusunu destekler niteliktedir. ${ }^{56}$ Anlaşılan o ki para ve güce sahip olan kimseler dilediği gibi hareket edebilmektedir. Beyoğlu Tevkifhanesiyle ilgili olarak karşımıza çıkan belgelerde tespit ettiğimiz şikâyetlerden biri diğeri de görüşme saatlerinin her tutuklu için eşit bir şekilde sunulmamış olması ve bazı mahkûmlara toleranslar tanınması üzerinedir. ${ }^{57}$ Bu durum da güce ve paraya bağlı bir eşitsizliği

\footnotetext{
52 Michel Foucault, Hapishanenin Doğuşu, İmge Kitabevi, Ankara, 1992, s. 251- 254.

53 Yıldız, a.g.e., s. 439.

${ }^{54}$ Yıldıztaş, a.g.e., s. 63; Memur maaşları ve yaşam standartlarıyla ilgili bknz. Carter V. Findley, Ottoman Civil Officialdom: A Social History, Princeton University Press, 1989, s. 293- 332.

55 Ebubekir Sofuoğlu, "Osmanlı Hapishanelerinde Islah ve Firar Teşebbüsleri", Hapishane Kitabı, İstanbul, 2010, s. 168: Beyrut hapishanesinde yaşanan bir kavgadaki firar teşebbüsünün başarısızıı̆ının ardından "iki ünlü kişi” tarafından başlatılan kavga neticesinde yaralama ve ölümler olmuştur.

56 Yıldız, a.g.e., s. 321- 322.

57 BOA, DH. MB. HPS. M, 39/ 9, 6 Ağustos 1335 (6 Ağustos 1919). "Beyoğlu jandarma taburu kumandanlığından bu kerre alınan raporda son zamanlarda Galatasaray
}

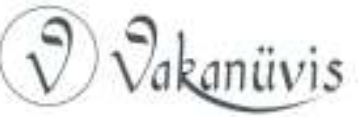


işaret eder. Haliyle gardiyan ve müdürlerin bu bağlamda usulsüzlük yapmış oldukları da açık bir şekilde ortadadır.

Beyoğlu Tevkifhanesindeki firar hadiselerine bakıldığında ise tutukluların kaçmalarına sadece göz yuman gardiyanlar olduğu gibi kaçış planının parçası olan gardiyanlar da bulunmaktadır. 1919 yılı Ekim ayında yaşanılan firarda pencerelerin kesilmesi için gerekli olan testereyi temin eden kişinin bizzat gardiyan olduğunun anlaşılması, firar sırasında gardiyanın doğrudan katılımını göstermektedir. ${ }^{58} \mathrm{Bir}$ diğer örnek ise 25 Temmuz 1919 tarihinde, görüş sırasında Ser gardiyanın doğrudan kapıcıya emir vermek suretiyle, hırsızlık suçundan tevkif edilmiş Hüseyin isimli bir kimsenin kaçışının sağlanmış olduğu müdür tarafından itiraf edilmiştir. ${ }^{59}$

Muhakkak gardiyan ve müdürlerin başına buyruk hareket etmelerinin sebebi sadece ekonomik olarak açıklanamaz çünkü tutuklulardan bazıları; katil, mütecasir, cevval vb. her şeyi yapmaya meyilli olduğu için tutuklanmıştır. Dolayısıyla tevkifhane ve hapishanelerdeki görevlilerin korkmuş olmaları da özellikle Arap Abdo gibi "Sayılı Fırtınalar"ın İstanbul'daki faaliyetleri düşünüldüğünde göz önünde tutulması gereken bir konudur. ${ }^{60} \mathrm{Bu}$ doğrultuda gardiyanların maaşlarının hâlihazırda olan ihtiyaçlarını karşılayamayacak mertebede olduğu bürokrasi tarafından da bilinmekte ve maaşlarının arttırıması gerektiği bildirilmektedir. Aynı belgede yaşanılan firar olaylarının bir diğer nedeninin de gardiyanların "... mânen ve maddeten ehl-i muktedir..." kimseler olmadığı biçiminde açıklanmaktadır. ${ }^{61}$

Tevkifhanesinde ziyaretleri için haftada bir iki gün tahsisi mutat temini-i intizam itibarıla elzem iken bu hususa ehemmiyet atfedilmemekle beraber mevkufları görüştürmek hususunda müsavat gözetilmediği, tevkighanekatib ve gardiyanlarının birçok hususta müdüre malumat vermeden iş yapıp intizamı ihlal etmekte bulunduklar.."

58 Yıldıztaş, a.g.e., s. 65.

59 BOA, DH. MB. HPS. M, 38/ 119, 25 Temmuz 1335 (25 Temmuz 1919); BOA, DH. MB.HPS. M, 39/ 03, 28 Temmuz 1335 (28 Temmuz 1919).

60 Bknz.: Reşat Ekrem Koçu, Istanbul Ansiklopedisi, C. 1, İstanbul, 1958, s. 29-30; Romanlar: Refi Cevad Ulunay, Sayılı Fırtınalar, İstanbul, 1973; Sermet Muhtar Alus, Onikiler, İstanbul, 1999.

${ }^{61}$ BOA, DH. MB.HPS. M, 94/ 48/ 2, 15 Temmuz 1335 (15 Temmuz 1919).

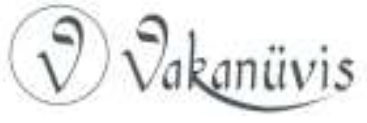


Gardiyanların hademe mi memur mu oldukları ve bu doğrultuda maaş ve izin gibi konuların düzenlenmesinin de sorun teşkil ettiği göze çarpmaktadır. ${ }^{62}$ Ayrıca elbise ve tayinatın verilmemesi, yediği yemeklerin tutuklularla aynı olması gibi hususlar düşünüldüğünde tüm bunlara ek olarak gardiyanlığın, halihazırda pek revaçta bir iş olmadığını göstermektedir. ${ }^{63} \mathrm{Bu}$ doğrultuda yukarıda bahsedilen "korku" sorunu ve ekonomik koşullar firarlardaki gardiyanların rollerini belirleyen unsurlardandır.

6 Ağustos 1919 tarihinde Dersaadet Jandarma Kumandanlığından yazılan bir belgede Beyoğlu Tevkifhanesi için "... ahlak ve seviye itibarıla ve daha kâmil gardiyanlar..." seçilmesi önerisi yapılmakla beraber ${ }^{64}$, gardiyanların usulsüzlüklerinin sürekli kontrol edilebilmesi için müdürlerin geceleri de çalışmaları ve fazla mesai için para ödemesi yapılması gündeme gelmiştir. Bir başka belgede ise müdürden iki gecede bir, gerektiğinde her gece tetkikler ve teftişler yapması istenmektedir. ${ }^{65}$ Tıpkı gardiyanların seçimi konusunda kullanılan muktedir kavramı, bir gereklilik olarak, sürekli açıklar veren ve firarlar sebebiyle zapt edilemeyen Beyoğlu Tevkifhanesinin müdürü için de kullanılmıştır. ${ }^{66}$ Firar hadisesiyle ilgili bir başka belgede yine "...heyet-i zabıtanın emek sarf ederek ele geçirdiği eşhasın böyle kolaylıkla kurtulmalarına sebebiyet vermek zabıtanın hayatını, memleketin asayişini ve ehemmiyetini hiçe saymak demektir..." ifadesiyle tevkifhanenin iki matuh (bunak) gardiyana teslim edildiğinden dem vurulmaktadır. ${ }^{67} \mathrm{Bu}$ olay bir tevkifhanede neden müdüre ihtiyaç duyulduğunun cevabı niteliğindedir.

\section{Mekteb-i Sultani ve Tevkifhane Komşuluğu}

Beyoğlu Tevkifhanesi ve Mekteb-i Sultani komşuluğu, İstanbul'un işlek ve yoğun olan Cadde-i Kebiri'nin, geceleri de renkli ve polisiye kalmasına neden olmuş görünmektedir. İleride detaylı olarak

\footnotetext{
62 Demirkol, a.g.e., ss. 182- 183.

63 Demirkol, a.g.e., ss. 70.

${ }^{64}$ BOA, DH. MB. HPS. M, 39/ 9, 6 Ağustos 1335 (6 Ağustos 1919).

65 BOA, DH. MB. HPS. M, 38/ 118, 25 Temmuz 1335 (25 Temmuz 1919).

${ }^{66}$ BOA, DH. MB. HPS. M, 39/ 9, 6 Ağustos 1335 (6 Ağustos 1919).

67 BOA, DH. MB. HPS. M, 38/102/1, Tarih Yok.
}

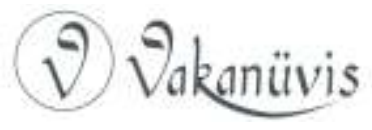


bahsedilecek olan firar hadiselerinde Mekteb-i Sultani bahçesi, tutuklular tarafından özgürlüğe ilk adım olarak kullanılmış olduğu için; okul, okul çalışanları ve öğrenciler de bu prison break öyküsünün bir parçası olmak zorunda kalmışlardır. Sık sık yaşanılan firar hadiseleri nedeniyle bahçeye atlayan zabıta memurları, silah sesleri ve hatta bahçeye atılan süprüntü ve çöpler öğrenciler için heyecan ve telaş nedeni olmuştur. ${ }^{68}$ Yerli yersiz sürekli karakol penceresinden okula giren zabıta memurları yetmezmiş gibi, bu yolu -yani karakol penceresini- okula geç kalan öğretmenlerin de kullandığını görmekteyiz. ${ }^{69}$ Bu tuhaf "komşuluk" ilişkisinde "mahrem" olan alanın buharlaştığı, iki mekân arasındaki ana arter haline gelmiş pencerenin de, devletin olmayan imkânlarından olsa gerek, meşrulaştığı ya da görmezden gelindiği trajikomik bir süreç yaşanmıştır.

Konumu itibariyle okulla organik bağ kuran bu tevkifhanenin, ağır suçlulara da ev sahipliği yapması ve özellikle firar sırasında okul ve okuldakilerle doğrudan temasları, kullanılan silahlar vb. gibi koşullar öğrenciler için heyecan ve telaşa sebebiyet vermiştir. Ancak 22 Temmuz 1919 yılında Beyoğlu Tevkifhanesindeki tutuklulardan duvarcı Hikmet ve Jandarma nam Kemal'in barut atacağı ve dışarıdan yardım alarak bomba kullanacakları haberi, yaşanabilecek olayların her zaman masumane olamayacağını ve hatta bu tür patlayıcıların etkileri düşünüldüğünde ne tür vahim sonuçlar doğurabileceğini göstermesi açısından çok önemlidir. ${ }^{70}$

Belgelerde doğrudan bir açıklamada bulunulmamış olsa da 1919 yılı, özellikle Temmuz ve Ağustos ayları boyunca sık sık yaşanan firar vakaları ve bunun okulla olan ilişkisine geçmeden önce, tespit edilen firarlardan farklı olarak ayrıca bir isyan girişimi de olmuştur. 1-2 Temmuz 1919 yılı gecesi gerçekleşen bu isyan girişimi, telefonla haber alınmasının ardından merkezdeki on beş nefer ve iki zabıtanın olay mahalline gelerek müdahalesiyle bastırılmıştır. ${ }^{71}$

\footnotetext{
68 BOA, DH. MB. HPS. M, 111/ 15/ 2, 7 Temmuz 1335 (7 Temmuz 1919).

${ }^{69}$ BOA, DH. MB. HPS. M, 111/ 15/ 4, 14 Temmuz 1335 (14 Temmuz 1919).

70 BOA, DH. MB. HPS. M, 38/ 106, 22 Temmuz 1335 (22 Temmuz 1919).

${ }^{71}$ BOA, DH. MB. HPS. M, 38/ 66, 2 Temmuz 1335 (2 Temmuz 1919).
}

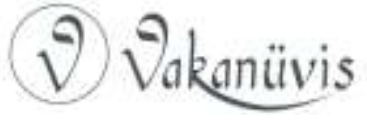


Tevkifhanedeki firar vakalarının çoğu, Mekteb-i Sultani bahçesine atlanılarak gerçekleştirilmiştir. 22 Temmuz 1919 tarihinde tevkifhane aşçısının oğlu tarafından yardım edilen ve aşçının da yokluğunu fırsat bilen mahkumlar, mutfağın duvarını delerek Mekteb-i Sultani'nin bahçesine atlamışlardır. ${ }^{72}$ Polis merkezinin verdiği bilgiye göre gardiyanların kayıtsızlığı neticesinde gerçekleşen bu firar hadisesinde güvenlik güçlerinin hemen haber almasıly tutuklular yakalanabilmiştir. ${ }^{73}$ Başka bir evrakta bahsedilen firar hadisesi ise filmleri aratmayacak türdendir. 15 Temmuz 1919 gecesi Galatasaray Tevkifhanesinde çeşitli suçlulardan olan Yorgi, Lazari, Hristo ve birkaç Rum, akşam teneffüsü sırasında gardiyan odasının yanında kiler olarak kullanılan odanın kapısını kırarak içeri girip, akşam dokuz buçuğa kadar gizlenmişler ve daha sonra duvara bir delik açarak mektep bahçesine atlamak suretiyle firar etmişlerdir. Olay mahallindeki piyadeler tarafından görülen tutuklular ve zanlılardan sadece Hristo'nun başarılı olduğu görülmektedir. ${ }^{74}$

9 Ağustos 1919 tarihli bir diğer firar olayı ise yine Mekteb-i Sultani bahçesine nazır olan pencerelerden biri kesilerek gerçekleşmiştir. Okul bahçesi tarafına bakan jandarma, aşırı yağmurdan kendisini korumaya çalıştığı bir sırada tutukluların kaçtığını gördükten sonra bir el ateş etmiş ve bunun sonucunda gardiyan ve polisler olay yerine gelerek müdahale etmişlerdir. Kaçmaya çalışan dokuz tutukludan sadece yedisinin yakalandığı bu vakada, iki tutuklu kaçmayı başarırken, birisi

72 BOA, DH. MB. HPS. M, 38/ 102. 3, 22 Temmuz 1335 (22 Temmuz 1919); BOA, DH. MB. HPS. M, 38/ 112, 22 Temmuz 1919 (22 Temmuz 1919).

${ }^{73}$ BOA, DH. MB. HPS. M, 38. 102/ 1.: Belge yaşanılan firarlarla ilgili olarak geniş bilgiler vermektedir: “...Beyoğlu hapishanesinde hemen her hafta firar vukuatı eksik değildir. Çünkü koca bir hapishane bir iki mâtuh (bunak) gardiyanın eline terk edilmektedir cinayetle lüzum-ı muhakemelerine karar verilmiş yirmi otuz kişinin hapishane-i umumiyeye icra-yı nakilleri suretiyle müddeiumumilikçe firar tehlikesine bir derece önüne geçmek istenmiş ise de hapishane-i umumiyye müdüriyeti bunların kabullerine dair emir telakki etmediğinden bahisle geriye iade eylemiştir. İşte bu akşamki firar tertibatını tehyie idenler (?) bir itiraz ile iade edilmiş canilerdir. Heyet-i zabıta emek sarf ederek ve kurban vererek ele geçirdiği eşhasın böyle kolaylıkla kurtulmalarına sebebiyet vermek zabıtanın hayatını, memleketin asayişini ve emniyetini hiçe saymak demektir..."

74 BOA, DH. MB. HPS. M, 38/ 90/ 1, 15 Temmuz 1335 (15 Temmuz 1919).

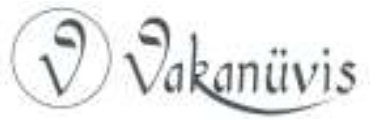


de düştüğü için yaralanıp hastaneye kaldırılmıştır. ${ }^{75}$ Bu firar vakasında dikkate değer bir başka konu ise yine jandarmanın ateş etmesine kadar olan sürede gardiyanların bu hadiseden haberinin olmamasıdır.

14 Temmuz 1919 tarihli bir başka belgede bahsedilen firar hadisesi gece saat dörtte gerçekleşmiştir. Tüfek seslerinin okul bahçesinden geldiğini iddia eden güvenlik güçleri, kapalı bulunan okul kapısını kırarak içeri girmiş, olayın duvarın delinmekte olduğunu hisseden jandarmanın ateş etmesi sebebiyle gerçekleştiğini öğrendikten sonra geri çekilmişlerdir. Yaşanılan bu sert müdahaleden iki gün önce de okuldakilerin yine duvarın delinmekte olduğunu ihbar etmeleri sonucunda silahlı jandarmalar, okul bahçesinde sabaha kadar nöbet tutmuşlardır. Tutukluların neredeyse her gün giriştikleri bu firar eylemleri nedeniyle, sürekli okul içinde ve etrafında silahlı güvenlik güçlerinin bulunması, silahların atılması, okulu rahatsız etmiştir. ${ }^{76} \mathrm{Bu}$ rahatsızlığın ardından okul müdüriyeti tarafından "...talebenin selameti için masrafı mektepten tesviye edilmek üzere pencerelere demir parmaklık vaz'ı hakkındaki teklifin..." bile bir çözüm olmadığı, okulun bu sorunlar üzerine elinden geleni yapmaya çalıştığını ancak tüm bunlara rağmen başarısız olduğunu görmekteyiz. ${ }^{77}$

\section{Sonuç}

XIX. yüzyıl önemli bürokratik ve hukuki dönüşümlerin yaşandığı bir dönem olmuştur. Ceza Kanunları, hapishaneler, meclisler, savcılık gibi yargı enstrümanlarının işleme sokulması, geleneksel devlet yapısından merkezi devlete geçişin, yani bir tür deri değiştirmenin göstergesidir. Balkan ve Birinci Dünya Harbi gibi iki büyük savaş, İstanbul'un işgali gibi siyasi dinamikler ve devletin ekonomik olarak zayıf olması gibi vakalar neticesinde hapishanelerle ilgili yapılan reformlar sağlıklı bir şekilde yürütülememiş ve istenilen başarı elde edilememiştir. 1919 yılı Beyoğlu Tevkifhanesinin fotoğrafı da tüm bu dönüşümlerin, pratikteki pürüzlerini gösterir türdendir. Örneğin bir yıl boyunca yaşanan izdihamın en büyük sebebi, ağır işleyen mahkeme sürecidir ve bu yüzden insanlar, sağlıksız koşullarda ve çok küçük odalarda gereğinden

\footnotetext{
75 BOA, DH. MB. HPS. M, 39/ 21/ 1- 2, 9 Ağustos 1335 (9 Ağustos 1919).

76 BOA, DH. MB. HPS. M, 111/ 15/ 4, 10 Temmuz 1335 (10 Temmuz 1919).

77 BOA, DH. MB. HPS. M, 111/ 15/ 2, 7 Temmuz 1335 (7 Temmuz 1919).
}

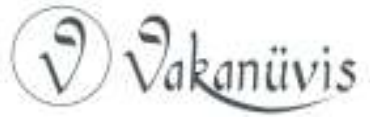


uzun sürede beklemek zorunda kalmıştır. Gardiyanların ücretlerinin az olması, eğitimsizlik ve iyi çalışacak gardiyanların eksikliği de devletin bahsedilen problemlerin görünür nedenlerindendir.

Bir diğer konu ise Mekteb-i Sultani ve Beyoğlu Galatasaray Tevkifhanesinin organik komşuluğudur. Bir medeniyet belirtisi olarak da algılanan hapishaneler ve tevkifhaneler genellikle merkezi yerlerde konumlandırımıştır. Ancak bahsedilen kurumlarda ağır suçluların tutuklu olarak bulunması, özellikle Beyoğlu Galatasaray Tevkifhanesinde bomba kullanma tehdidinin bile olduğu düşünüldüğünde, İstanbul'un en işlek caddelerinden olan Cadde-i Kebir'de bulunan sivillerin veya hemen yanında bulunan okul öğrencilerinin zarar görme ihtimalini tahmin etmek zor değildir.

Yukarıdaki örneklerden hareketle, gardiyanların ihmalleri neticesinde gerçekleşen firar vakalarında, tutukluların ve yer yer de mahkumların doğrudan okulu kullanmaları; okul, okul çalışanları ve öğrenciler için heyecan ve korku sebebi olmuştur. Okulda neredeyse her gün güvenlik güçlerinin bulunması, uzun bekleyişler, silah sesleri, 1919 yııının fotoğrafı için gayet olağandır. Okula bakan bir pencerenin korumasız olması sebebiyle okula giriş çıkışları alışkanlık haline getiren güvenlik görevlileri, mahkumlar ve tutuklular yetmezmiş gibi geç kalan hocaların bile okul girmek için bu pencereyi kullanmaları, gardiyanların inmalleri de düşünülürse, usulsüzlügün sıradanlığını göstermektedir. Bitirmeden önce, firarların engellenebilmesinde tevkifhanenin yanında bulunan Beyoğlu Mutasarrıflığının önemli görevler üstlendiğinin altı çizilmelidir. Mutasarrıflığın hazır bulunan güvenlik güçlerinin olay mahalline hızlıca intikal edebilmeleri sebebiyle çoğu firari yakalanabilmiş, okul çalışanlarının ve öğrencilerin yaşayabilecekleri kötü olayların önüne geçilebilmiştir.

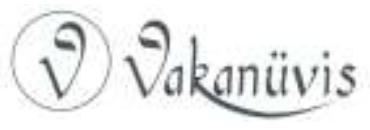




\section{Kaynakça}

\section{Başbakanlık Osmanlı Arşivi (BOA)}

Mebânî-i Emîriye ve Hapishâneler Müdüriyeti Belgeleri

38/102-1-3; 38/119; 38/112; 38/ 90-1; 38/66; 38/106; 38/ 118; 38/105-12; 38/74; 38/121; 39/8; 39/9; 39/03-1; 94/48-2; 111/15-2-4; 39/21 1-2.

\section{Araştırma ve İnceleme Eserler}

Akyıldız, Ali, Osmanlı Bürokrasisi ve Modernleşme, İstanbul 2012.

Alus, Sermet Muhtar, Onikiler, İstanbul 1999.

Bozkurt, Gülnihal, "Tanzimat ve Hukuk", Tanzimat'ın 150. Yıldönümü Uluslararası Sempozyumu, Ankara 1994, ss. 271- 285.

Demirel, Fatmagül, "Osmanlı Adliye Teşkilatında Yaşanan Sorunların Hapishanelere Yansıması (1876- 1909)", Osmanlı'da Asayiş, Suç ve Ceza, Der: Levy, N., Toumarkine, A., İstanbul 2010, ss. 190-200.

Demirkol, Kurtuluş, II. Meşrutiyet Döneminde Edirne Vilayeti Hapishaneleri, Yayınlanmamış Doktora Tezi, Sakarya, 2012.

Demiryürek, Halim, Osmanlı Hapishaneleri (1913- 1914), Babıali Kültür Yayıncılı̆̆ı, İstanbul, 2019.

Findley, Carter V., Ottoman Civil Officialdom: A Social History, Princeton, 1989.

Foucault, Michel, Hapishanenin Doğuşu, İmge Kitabevi, Ankara, 1992.

Foucault, Michel, Iktidarın Gözü Seçme Yazılar 4, Ayrıntı Yayınları, İstanbul, 2012.

Gulbenkian Komisyonu, Sosyal Bilimleri Açın: Sosyal Bilimlerin yeniden Yapılanması Üzerine Rapor, İstanbul 2012.

Koçu, Reşat Ekrem, İstanbul Ansiklopedisi, C.1, İstanbul 1958.

Kortantamer, Samira, "Memlüklerde Hapishaneler", Hapishaneler Kitabı, İstanbul 2010, ss. 93- 101.

Levy-Aksu, Noemi, Osmanlı İstanbulu'nda Asayiş 1879- 1909, İstanbul 2017.

Ortaylı, İlber, Hukuk ve Idare Adamı Olarak Osmanlı Devleti'nde Kadı, İstanbul 2018.

Özkul, Ali Eftal, "XVIII. Yüzyılın İlk Yarısında Kıbrıs'ta Kalebentler ve Cezirebentler", Hapishaneler Kitabı, İstanbul 2010, ss. 130- 143.

Öztürk, Necdet, "Osmanlılarda Hapis Olayları (1300-1512)”, Hapishaneler Kitabı, İstanbul 2010, ss. 101-130.

Roth, Mitchel P., Göze Göz Suç ve Cezanın Küresel Tarihi, Can Yayınları, İstanbul, 2017.

Schull, Kent, "Tutuklu Sayımı: Jön Türklerin Sistematik Bir Şekilde Hapishane İstatistikleri Toplama Çalışmaları ve Bunların 1911-1918 Hapishane

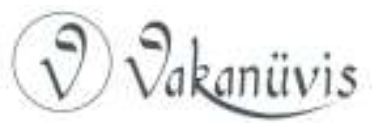


Reformu Üzerine Etkileri”, Osmanlı'da Asayiş, Suç ve Ceza, Der: Levy, N., Toumarkine, A., İstanbul 2010, ss. 212-238.

Schull, F. Kent, Prisons in the Late Ottoman Empire Microcosms of Modernity, Edinburgh 2014.

Saner Gönen, Yasemin, “Osmanlı Hapishaneleri İyileştirme Girişimi, 1917 Yılı, Hapishaneler Kitabı, İstanbul 2010, ss. 173- 184.

Saner Gönen, Yasemin, “Osmanlı’nın Yüzlerce Yıl Süren Cezalandırma ve Korkutma Refleksi: Prangaya Vurma”, Osmanlı'da Asayiş, Suç ve Ceza, Der: Levy, N., Toumarkine, A., İstanbul 2010, ss. 163- 190.

Sofuoğlu, Ebubekir, "Osmanlı Hapishanelerinde Islah ve Firar Teşebbüsleri", Hapishaneler Kitabı, İstanbul 2010, ss. 163- 173.

Sultan II. Abdülhamid Arşivi İstanbul Fotoğrafları, İstanbul 2008.

Şen, Hasan, "Osmanlı'da Hapishane Mefhumu", Osmanlı'da Asayiş, Suç ve Ceza, Der: Levy, N., Toumarkine, A., İstanbul 2010, ss. 200-212.

Ulunay, Refi' Cevad, Sayılı Fırtınalar, İstanbul 1973.

Yalçın, Ayça, Cezaevlerinde Hükümlü Yaşama Hacimlerinin lç Mekân Düzenlemesi, Yayımlanmamış Yüksek Lisans Tezi, Ankara 2003.

Yıldız, Gültekin, Mapushane Osmanlı Hapishanelerinin Kuruluş Serüveni, Kitabevi Yayınları, İstanbul, 2012.

Yıldıztaş, Mümin, Mütareke Döneminde Suç Unsurları ve istanbul Hapishaneleri, Yayımlanmamış Yüksek Lisans Tezi, İstanbul 1997.

\section{Internet Kaynakları}

Alus, Sermet Muhtar, "Eski Beyoğlu Mutasarrıflığı”, İstanbul Şehir Üniversitesi Online Erişim: 20. 04. 2019, http://earsiv.sehir.edu.tr:8080/xmlui/bitstream/handle/11498/1273/001500 647006.pdf?sequence=3\&isAllowed $=y$ 


\section{EKLER}

Ek-1: Galatasaray Mutasarrıflığı ve Hapishaneleri

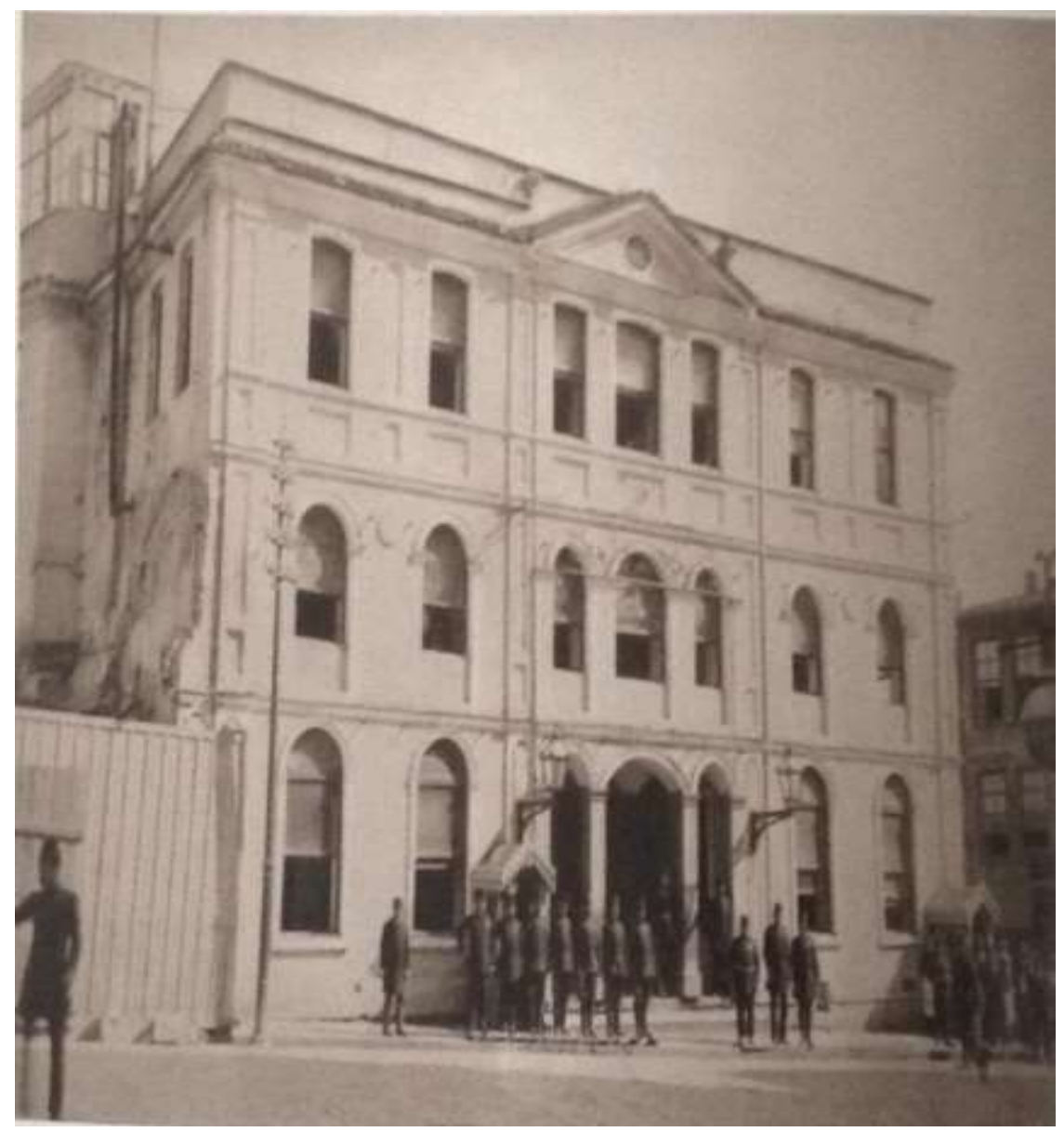

(v) Vakenüvis 
Ek-2: Beyoğlu Mutasarrıflığı Binası

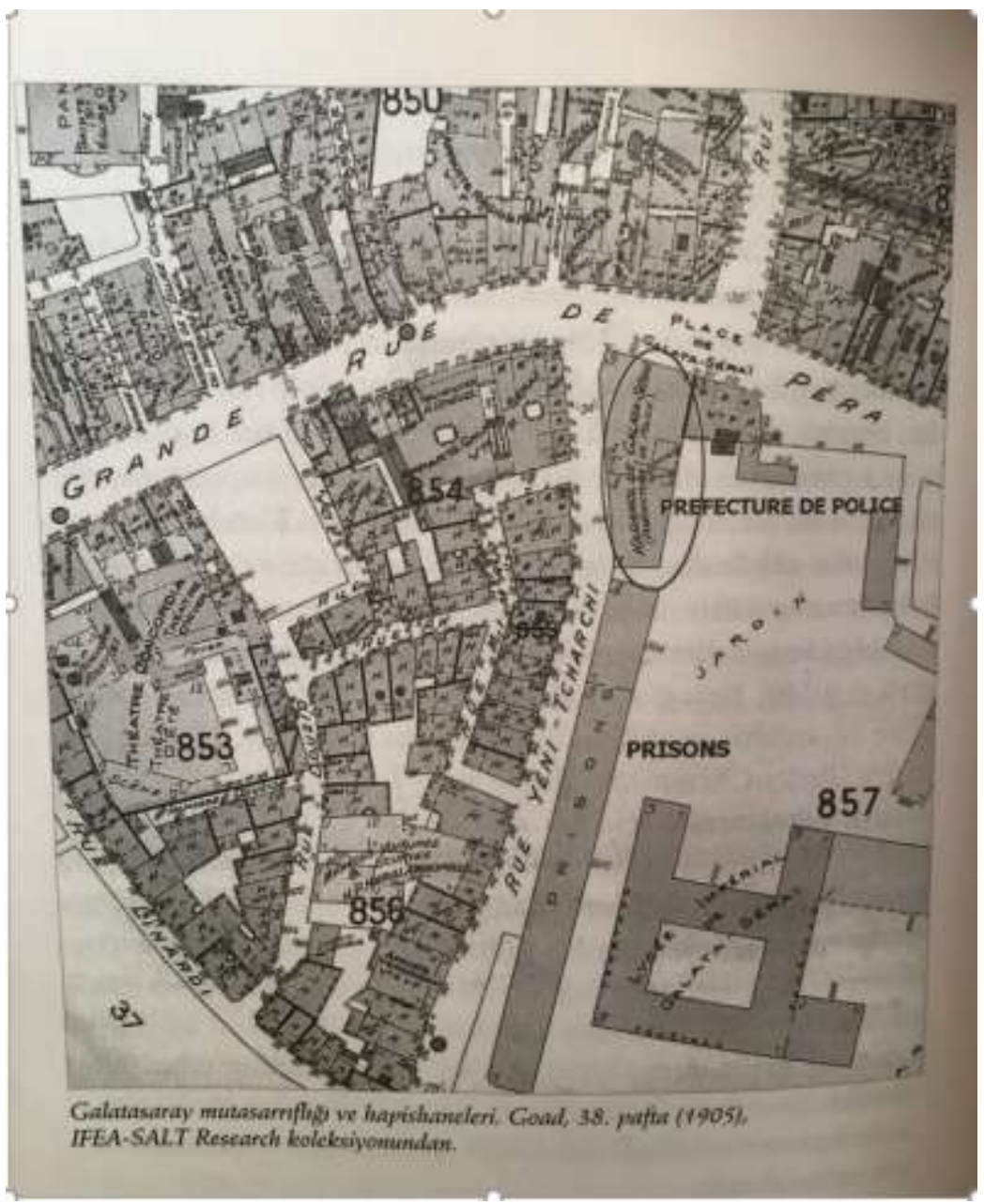

( V) Vakaniuvis 